\title{
Determination of Histidine Protonation States in Proteins by Fast Magic Angle Spinning NMR
}

\author{
Roman Zadorozhnyi ${ }^{1,2}$, Sucharita Sarkar ${ }^{1,2}$, Caitlin M. Quinn ${ }^{1}$, Kaneil K. Zadrozny ${ }^{3}$, \\ Barbie K. Ganser-Pornillos ${ }^{3}$, Owen Pornillos ${ }^{3}$, Angela M. Gronenborn ${ }^{2,4 \star}$ and \\ Tatyana Polenova ${ }^{1,2 *}$
}

${ }^{1}$ Department of Chemistry and Biochemistry, University of Delaware, Newark, DE, United States, ${ }^{2}$ Pittsburgh Center for HIV Protein Interactions, University of Pittsburgh School of Medicine, Pittsburgh, PA, United States, ${ }^{3}$ Department of Molecular Physiology and Biological Physics, University of Virginia School of Medicine, Charlottesville, VA, United States, ${ }^{4}$ Department of Structural Biology, University of Pittsburgh School of Medicine, Pittsburgh, PA, United States

OPEN ACCESS

Edited by: Amir Goldbourt, Tel Aviv University, Israel

Reviewed by: Loren B. Andreas, Max Planck Institute for Biophysical

Chemistry, Germany

Hans-Heinrich Limbach, Freie Universität Berlin, Germany

*Correspondence: Tatyana Polenova tpolenov@udel.edu Angela M. Gronenborn amg100@pitt.edu

Specialty section: This article was submitted to

Structural Biology,

a section of the journal Frontiers in Molecular Biosciences

Received: 30 August 2021 Accepted: 15 October 2021 Published: 10 December 2021

Citation:

Zadorozhnyi R, Sarkar S, Quinn CM, Zadrozny KK, Ganser-Pornillos BK,

Pornillos $O$, Gronenborn AM and Polenova $T$ (2021) Determination of Histidine Protonation States in Proteins by Fast Magic Angle Spinning NMR.

Front. Mol. Biosci. 8:767040.

doi: 10.3389/fmolb.2021.767040
Histidine residues play important structural and functional roles in proteins, such as serving as metal-binding ligands, mediating enzyme catalysis, and modulating proton channel activity. Many of these activities are modulated by the ionization state of the imidazole ring. Here we present a fast MAS NMR approach for the determination of protonation and tautomeric states of $\mathrm{His}$ at frequencies of $40-62 \mathrm{kHz}$. The experiments combine ${ }^{1} \mathrm{H}$ detection with selective magnetization inversion techniques and transferred echo double resonance (TEDOR)-based filters, in 2D heteronuclear correlation experiments.

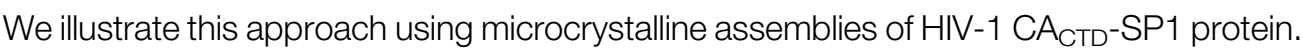

Keywords: Magic angle spinning (MAS), nuclear magnetic resonance (NMR) spectroscopy, histidine protonation state, transferred echo double resonance (TEDOR), Fast MAS NMR, solid-state NMR

\section{INTRODUCTION}

Histidines (His) play important structural and functional roles in proteins such as metal binding (Stryer et al., 1964; Perutz and Mathews, 1966; Adams et al., 1969; Liljas et al., 1972), proton transfer (Hoffee et al., 1967; Blow et al., 1969; Campbell et al., 1974), and stability (Perutz et al., 1969; Lewis et al., 1976; Loewenthal et al., 1992). These functions are often correlated with the ionization state of the histidine sidechain (Figure 1A) (Bachovchin and Roberts, 1978; Kossiakoff and Spencer, 1981; Lewis et al., 1981). While the $\mathrm{pK}_{\mathrm{a}}$ of the imidazole ring for free histidine is 6.5 (Blomberg et al., 1977), in proteins the $\mathrm{pK}_{\mathrm{a}}$ values vary widely, from 3 to 9 , depending on the interactions with neighboring residues and degree of burial (Zhou et al., 1993; Plesniak et al., 1996). At $\mathrm{pH}$ values above the $\mathrm{pK}_{\mathrm{a}}$, anionic $\tau$ and $\pi$ tautomers with hydrogens at either $\mathrm{N}^{\varepsilon 2}$ or $\mathrm{N}^{\delta 1}$ are present, while below the $\mathrm{pK}_{\mathrm{a}}$ the protonated imidazole ring possesses hydrogens at both $\mathrm{N}^{\varepsilon 2}$ and $\mathrm{N}^{\delta 1}$. For a protein at intermediate $\mathrm{pH}$ values, it is possible that a fraction of His residues is protonated and the remaining fraction unprotonated (French and Hammes, 1965; Edwards and Sykes, 1980; Hass et al., 2008).

Methods to determine His ionization states in proteins are solution NMR (Kilmartin et al., 1973; Markley, 1975; Bachovchin and Roberts, 1978; Perutz et al., 1985; Pelton et al., 1993; Shimba et al., 1998; Hass et al., 2008; Hansen and Kay, 2014) or neutron diffraction (Kossiakoff and Spencer, 1980; Maeda et al., 2004; Kovalevsky et al., 2010), with the latter limited to very large single crystals and requiring a neutron source, both difficult conditions to meet routinely. Therefore, solid-state magic angle spinning (MAS) NMR constitutes a viable alternative (Wei et al., 1999). Similar to solution NMR, the tautomeric state of histidines can be unambiguously determined from a unique combination of ${ }^{15} \mathrm{~N}$ sidechain chemical shifts (Munowitz et al., 1982; 


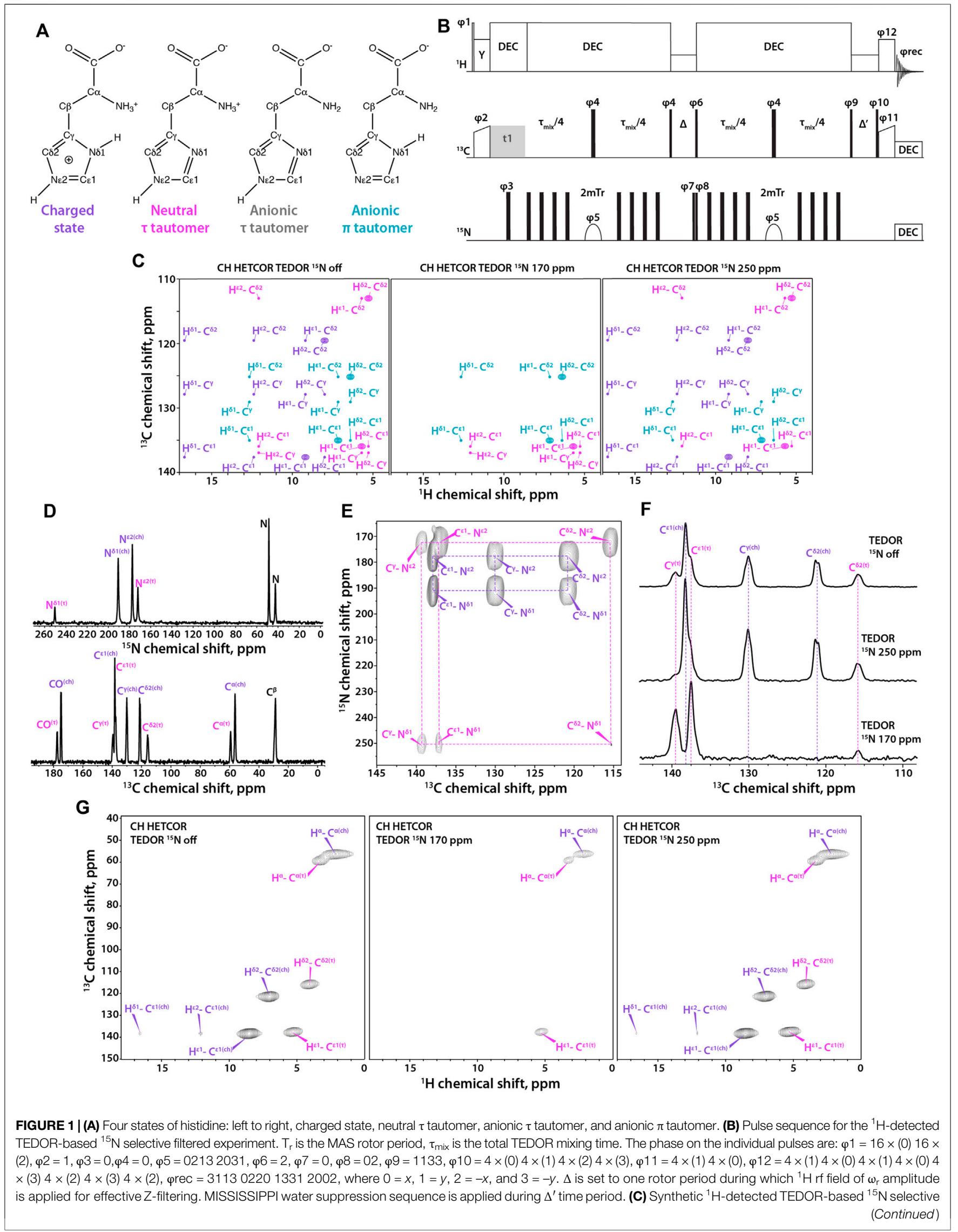


FIGURE 1 | filtered CH HETCOR spectra showing cross peaks expected for each tautomer. Left to right, soft pulse turned off, soft pulse at 170 ppm, soft pulse at 250 ppm. The filtering patterns for neutral and anionic $\tau$ tautomers are identical. (D) ${ }^{15} \mathrm{~N}$ (top) and ${ }^{13} \mathrm{C}$ (bottom) CPMAS NMR spectra of crystalline histidine. (E) Aromatic region expansion of 2D NCA spectrum of crystalline histidine. (F) $1 \mathrm{D}^{13} \mathrm{C}$ spectra using TEDOR-based ${ }^{15} \mathrm{~N}$ selective filtering in the aromatic region. Top to bottom, soft pulse turned off; soft pulse at 250 ppm; soft pulse at $170 \mathrm{ppm}$. (G) Three complementary ${ }^{1} \mathrm{H}$-detected TEDOR-based ${ }^{15} \mathrm{~N}$ selective filtered $\mathrm{CH}$ HETCOR spectra. Left to right, soft pulse turned off, soft pulse at 170 ppm, soft pulse at 250 ppm. The MAS frequency was $60 \mathrm{kHz}$ in all experiments. Signals of charged state are shown in purple, neutral $\tau$ tautomer - in magenta, anionic $\tau$ tautomer - in grey, and anionic $\pi$ tautomer - in teal.

Wei et al., 1999; Miao et al., 2014) and the corresponding N-H distances can be estimated, allowing for hydrogen bonding studies (Shenderovich et al., 2015). Protonation states for the crystalline histidine amino acid have been determined by MAS NMR for different $\mathrm{pH}$ values (Li and Hong, 2011) and crystalline short peptides (Platzer et al., 2014). Using ${ }^{15} \mathrm{~N}$ selective filtered, ${ }^{13} \mathrm{C}$-detected experiments with the inversion pulses at frequencies of the different tautomers (Miao et al., 2014) permits their identification. For proteins containing several histidine residues, the above experiments are challenging due to low sensitivity and spectral overlap. Therefore, only a handful of such studies have been reported to date (Hu et al., 2006; Hu et al., 2010; Miao et al., 2015; Kwon et al., 2019; Maciejko et al., 2019; Vasa et al., 2019; Movellan et al., 2020). In order to increase resolution, the original pulse sequence can be reconfigured as a $2 \mathrm{D}$ experiment by introducing a ${ }^{13} \mathrm{C}-{ }^{13} \mathrm{C}$ mixing period based on proton-driven spin diffusion (PDSD) (Bloembergen, 1949) and extending the second Z-filter (Miao et al., 2014). 2D and 3D proton-based experiments were also introduced with ${ }^{1} \mathrm{H}$ chemical shifts either recorded in the indirect dimension (Miao et al., 2015) or detected directly (Shenderovich et al., 2015; Vasa et al., 2019; Movellan et al., 2020).

Herein, we present an alternative MAS experiment that uses ${ }^{1} \mathrm{H}$ detected transferred-echo double resonance (TEDOR)based ${ }^{15} \mathrm{~N}$ selectively filtered $2 \mathrm{D}$ correlations at fast MAS frequencies of $40-60 \mathrm{kHz}$. The advantages of the ${ }^{1} \mathrm{H}$-detected fast-MAS experiments presented here are: i) improved sensitivity due to ${ }^{1} \mathrm{H}$ detection, and ii) improved resolution via the second dimension and selective recoupling of aromatic resonances directly attached to ${ }^{15} \mathrm{~N}$ atoms. Microcrystalline assemblies of $\mathrm{U}^{-13} \mathrm{C},{ }^{15} \mathrm{~N}$ - and fractionally deuterated (FD) (Mance et al., 2015) ${ }^{13} \mathrm{C},{ }^{15} \mathrm{~N}-\mathrm{HIV}-1$ $\mathrm{CA}_{\mathrm{CTD}}$-SP1 protein samples, possessing solely a single His residue, His-226, are ideally suited for pulse sequence optimization and therefore were selected for illustrating our current approach. Extension to ultrafast MAS frequencies (up to $110 \mathrm{kHz}$ ), should yield even higher sensitivity and resolution for proteins with multiple histidines.

\section{MATERIALS AND METHODS}

\section{Sample Preparation}

$\mathrm{U}-{ }^{13} \mathrm{C},{ }^{15} \mathrm{~N}$-L-histidine was purchased from Cambridge Isotope Laboratories, recrystallized from an aqueous solution at $\mathrm{pH} 6.0$, adjusted by mixing $\mathrm{HCl}$ and $\mathrm{NaOH}$. The sample was packed into a 1.3 mm MAS rotor. Microcrystalline assemblies of $\mathrm{U}_{-}^{-13} \mathrm{C},{ }^{15} \mathrm{~N}$ - and FD- ${ }^{13} \mathrm{C},{ }^{15} \mathrm{~N}-\mathrm{HIV}-1 \mathrm{CA}_{\mathrm{CTD}}-\mathrm{SP} 1$ were prepared in the presence of the assembly cofactor inositol hexakisphosphate (IP6) as described previously (Wagner et al., 2016) except for growing Escherichia coli in M9 medium containing ${ }^{13} \mathrm{C}$ glucose, ${ }^{15} \mathrm{~N}$ $\mathrm{NH}_{4} \mathrm{Cl}$, isotopically labeled precursors, and (for the deuterated sample) $\mathrm{D}_{2} \mathrm{O}$. Proteins were assembled with $1.6 \mathrm{mM}$ IP6 (Sigma-Aldrich), for a final reaction volume of $1 \mathrm{ml}$ at $\mathrm{pH}$ 8.0. Assemblies were incubated overnight at $20^{\circ} \mathrm{C}$ and packed into $3.2 \mathrm{~mm}\left(\mathrm{U}_{-}{ }^{13} \mathrm{C},{ }^{15} \mathrm{~N}\right), 1.9 \mathrm{~mm}\left(\mathrm{FD}_{-}{ }^{13} \mathrm{C},{ }^{15} \mathrm{~N}\right)$, or $1.3 \mathrm{~mm}$ MAS rotors $\left(\mathrm{U}_{-}{ }^{13} \mathrm{C},{ }^{15} \mathrm{~N}\right)$.

\section{MAS NMR Spectroscopy}

MAS NMR experiments on $\mathrm{U}^{13}{ }^{13} \mathrm{C},{ }^{15} \mathrm{~N}-\mathrm{CA}_{\mathrm{CTD}}-\mathrm{SP} 1$ and $\mathrm{FD}-{ }^{13} \mathrm{C},{ }^{15} \mathrm{~N}-\mathrm{CA}_{\mathrm{CTD}}$-SP1 microcrystalline assemblies were performed on a $20.0 \mathrm{~T}$ Bruker AVIII spectrometer outfitted with $3.2 \mathrm{~mm}$ E-Free $\mathrm{HCN}$ and $1.9 \mathrm{HCN}$ probes, respectively. The MAS frequency was 14 and $40 \mathrm{kHz}$, respectively, controlled to within $\pm 10 \mathrm{~Hz}$ by a Bruker MAS controller. The actual sample temperature was maintained at $4 \pm 1^{\circ} \mathrm{C}$ throughout the experiments using the Bruker temperature controller.

The Larmor frequencies were $850.4 \mathrm{MHz}\left({ }^{1} \mathrm{H}\right), 213.9 \mathrm{MHz}\left({ }^{13} \mathrm{C}\right)$ and $86.2 \mathrm{MHz}\left({ }^{15} \mathrm{~N}\right)$. The typical $90^{\circ}$ pulse lengths were $2.6-3.0 \mu$ s for ${ }^{1} \mathrm{H}, 4.3-4.5 \mu$ s for ${ }^{13} \mathrm{C}$, and $4.2-4.7 \mu$ s for ${ }^{15} \mathrm{~N}$. The ${ }^{1} \mathrm{H}_{-}{ }^{13} \mathrm{C}$ and ${ }^{1} \mathrm{H}_{-}{ }^{15} \mathrm{~N}$ cross-polarization employed a linear amplitude ramp of $90-110 \%$ on ${ }^{1} \mathrm{H}$, and the center of the ramp was matched to a Hartmann-Hahn condition at the first spinning sideband; contact times of $0.7-1.5 \mathrm{~ms}$ and 1.0-1.7 ms were used, respectively. $50 \mathrm{~ms}$ CORD (Hou et al., 2013) mixing time was applied to facilitate ${ }^{13} \mathrm{C}-{ }^{13} \mathrm{C}$ mixing.

MAS NMR experiments on $\mathrm{U}_{-}{ }^{13} \mathrm{C},{ }^{15} \mathrm{~N}$-L-histidine and $\mathrm{FD}-{ }^{13} \mathrm{C},{ }^{15} \mathrm{~N}-\mathrm{CA}_{\mathrm{CTD}} \mathrm{SP} 1$ microcrystalline assemblies were performed on a $14.1 \mathrm{~T}$ Bruker AVIII spectrometer outfitted with $1.3 \mathrm{~mm} \mathrm{HCN}$ probe. Larmor frequencies were $599.8 \mathrm{MHz}$ $\left({ }^{1} \mathrm{H}\right), 150.8 \mathrm{MHz}\left({ }^{13} \mathrm{C}\right)$, and $60.7 \mathrm{MHz}\left({ }^{15} \mathrm{~N}\right)$. The MAS frequency was $60 \mathrm{kHz}$, controlled to within $\pm 10 \mathrm{~Hz}$ by a Bruker MAS controller. The actual sample temperature was maintained at $40 \pm 1^{\circ} \mathrm{C}$ throughout the experiments using the Bruker temperature controller. The typical $90^{\circ}$ pulse lengths were $1.4-1.6 \mu$ s for ${ }^{1} \mathrm{H}, 2.7-3.0 \mu$ s for ${ }^{13} \mathrm{C}$, and 3.3-3.6 $\mu$ s for ${ }^{15} \mathrm{~N}$. The ${ }^{1} \mathrm{H}-{ }^{13} \mathrm{C}$ and ${ }^{1} \mathrm{H}_{-}{ }^{15} \mathrm{~N}$ cross-polarization employed a linear amplitude ramp of $90-110 \%$ on ${ }^{1} \mathrm{H}$, center of the ramp was matched to a Hartmann-Hahn condition at the first spinning sideband, with contact times of $1.0-5.0 \mathrm{~ms}$ and $1.3-5.0 \mathrm{~ms}$, respectively. Band-selective ${ }^{15} \mathrm{~N}-{ }^{13} \mathrm{C}$ SPECIFIC-CP contact time was 5.0-6.0 ms. SWFTPPM (Vinod Chandran et al., 2008) decoupling $(15 \mathrm{kHz})$ was used during the TEDOR block and acquisition periods. The selective ${ }^{15} \mathrm{~N} 180^{\circ}$ r-SNOB (Kupce et al., 1995) pulse length in the Z-filtered TEDOR experiments was $500 \mu$ s and the bandwidth $2 \mathrm{kHz}$; the rf power was $4 \mathrm{kHz}$. During the Z-filter time period $\Delta$, $60 \mathrm{kHz} \mathrm{CW}$ decoupling was applied for $\tau_{\mathrm{r}}$ on ${ }^{1} \mathrm{H}$ channel, while during the time period $\Delta^{\prime}$, MISSISSIPPI (Zhou and Rienstra, 2008) water suppression was applied. The TEDOR block duration was 1-3 ms. 

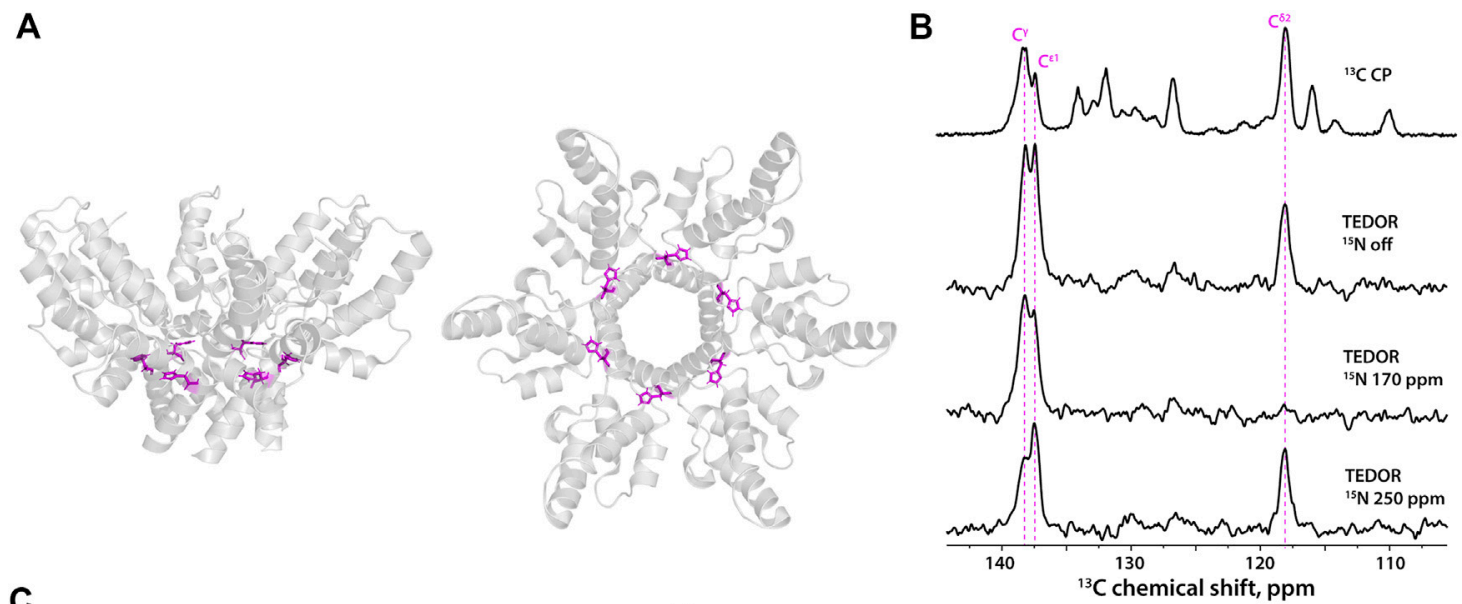

C

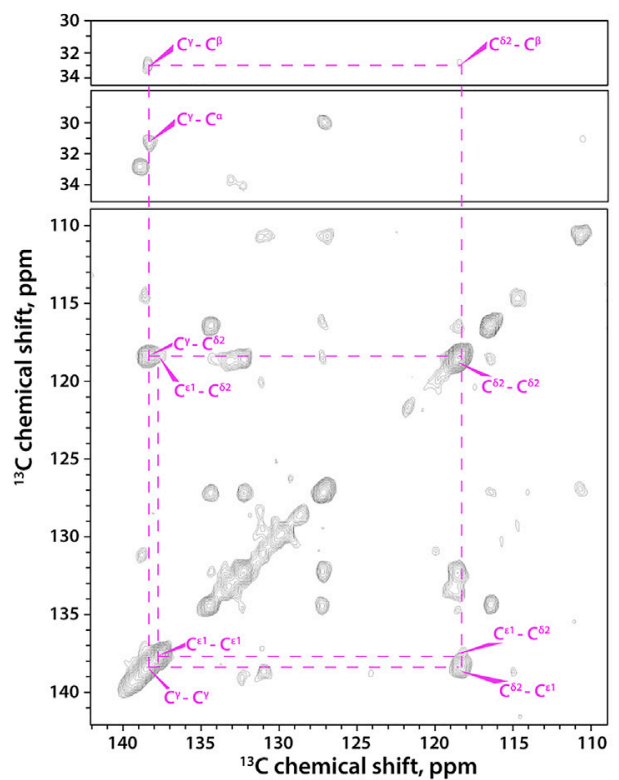

D

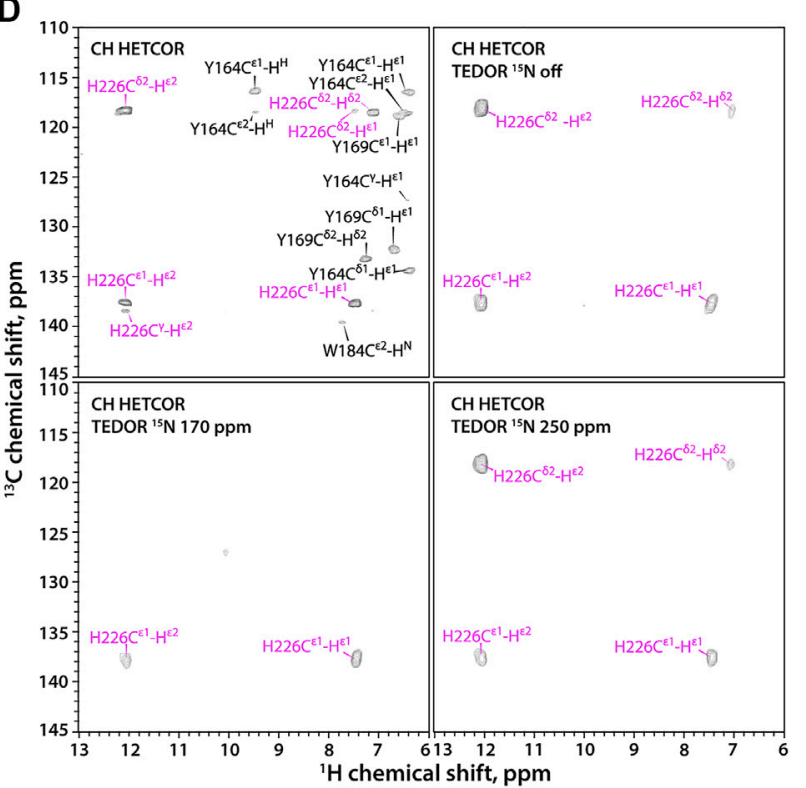

FIGURE 2 | (A) A hexameric unit of HIV-1 CA ${ }_{C T D}$-SP1 in the microcrystalline assembly (PDB 5I4T) shown as side view (left) and top view (right). (B) $1 \mathrm{D}{ }^{13} \mathrm{C}$ MAS NMR spectra of $\mathrm{FD}-{ }^{13} \mathrm{C},{ }^{15} \mathrm{~N}-\mathrm{CA}_{\mathrm{CTD}}-\mathrm{SP} 1$ with TEDOR-based ${ }^{15} \mathrm{~N}$ selective filtering in the aromatic region. Top to bottom: CPMAS spectrum; TEDOR-based ${ }^{15} \mathrm{~N}$ selectively filtered spectra with soft pulse turned off, soft pulse at $170 \mathrm{ppm}$, and soft pulse at $250 \mathrm{ppm}$. (C) 2D CORD spectrum of FD- ${ }^{13} \mathrm{C},{ }^{15} \mathrm{~N}-\mathrm{CA} \mathrm{ATD}_{\mathrm{CTD}}-\mathrm{SP} 1$ (MAS frequency $14 \mathrm{kHz}$ ). (D) Aromatic regions of ${ }^{1} \mathrm{H}$-detected TEDOR-based ${ }^{15} \mathrm{~N}$ selective filtered $\mathrm{CH}$ HETCOR spectra in FD- ${ }^{13} \mathrm{C},{ }^{15} \mathrm{~N}$-CA $\mathrm{CTD}$-SP1: TEDOR filter and soft pulse turned off (top left), soft pulse turned off (top right), soft pulse at 170 ppm (bottom left), soft pulse at $250 \mathrm{ppm}$ (bottom right). The MAS frequency was $40 \mathrm{kHz}$ in all experiments, unless indicated otherwise. Signals of $\tau$ tautomer are shown in magenta.

\section{Data Processing}

All MAS NMR data were processed using NMRPipe (Delaglio et al., 1995). The ${ }^{13} \mathrm{C}$ and ${ }^{15} \mathrm{~N}$ chemical shifts were referenced with respect to the external standards adamantane (Morcombe and Zilm, 2003) and ammonium chloride (Bertani et al., 2014), respectively. The $2 \mathrm{D}$ and $3 \mathrm{D}$ data sets were processed by applying 30, 45, 60, and $90^{\circ}$ shifted sine bell apodization followed by a Lorentzian-to-Gaussian transformation in both dimensions. Forward linear prediction to twice the number of the original data points was used in the indirect dimension followed by zero filling. The processed spectra were analyzed in NMRFAM-Sparky (Goddard and Kneller, 2004; Lee et al., 2015) and CCPN (Stevens et al., 2011).

\section{RESULTS}

Here, we report on a 2D ${ }^{1} \mathrm{H}$-detected TEDOR-based Z-filtered experiment, which incorporates ${ }^{15} \mathrm{~N}$ selective filters for the determination of histidine tautomeric states. The pulse sequence is shown in Figure 1B. The experiment is well suited for fast MAS frequencies of $40 \mathrm{kHz}$ and above. The tautomeric states of His residues are unambiguously determined using a combination of three $\mathrm{CH}$ HETCOR experiments comprising: i) ${ }^{15} \mathrm{~N}$ selective TEDOR filter, containing ${ }^{13} \mathrm{C}$ resonances of all protonation and tautomeric states present; ii) ${ }^{15} \mathrm{~N}$ selective TEDOR filter with a soft pulse at $170 \mathrm{ppm}$, removing resonances of the protonated state while $\mathrm{C}^{\varepsilon 1}$ and $\mathrm{C}^{\delta 2}$ atoms of $\pi$ tautomer and $\mathrm{C}^{\varepsilon 1}$ and $\mathrm{C}^{\gamma}$ atoms of $\tau$ tautomer 

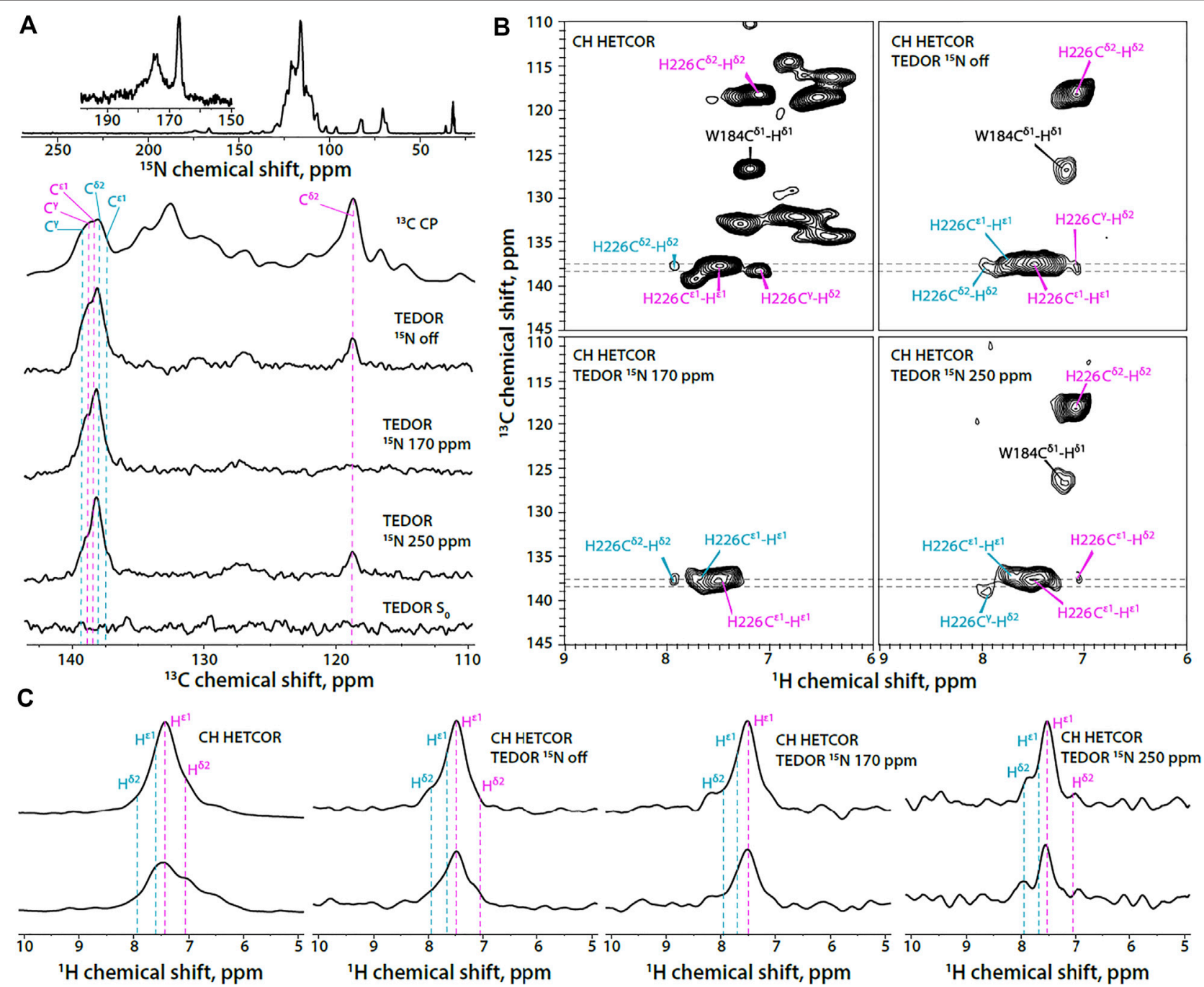

FIGURE 3 | (A) $1 \mathrm{D}^{15} \mathrm{~N}$ CPMAS and ${ }^{13} \mathrm{C}$ MAS NMR spectra of $\mathrm{U}-{ }^{13} \mathrm{C},{ }^{15} \mathrm{~N}-\mathrm{CA} \mathrm{C}_{\mathrm{CD}}-\mathrm{SP} 1$ with TEDOR-based ${ }^{15} \mathrm{~N}$ selective filtering in the aromatic region (MAS frequency $14 \mathrm{kHz}$ ). Top to bottom: ${ }^{15} \mathrm{~N}$ CPMAS spectrum; ${ }^{13} \mathrm{C}$ CPMAS spectrum; TEDOR-based ${ }^{15} \mathrm{~N}$ selectively filtered spectra with soft pulse turned off, soft pulse at $170 \mathrm{ppm}$, soft pulse at $250 \mathrm{ppm}$, and a reference $\left(\mathrm{S}_{0}\right)$ experiment. (B) Aromatic regions of ${ }^{1} \mathrm{H}$-detected TEDOR-based ${ }^{15} \mathrm{~N}$ selective filtered $\mathrm{CH}$ HETCOR spectra in U- ${ }^{13} \mathrm{C}$, ${ }^{15} \mathrm{~N}$-CA $\mathrm{CTD}^{-}$ SP1: TEDOR filter and soft pulse turned off (top left), soft pulse turned off (top right), soft pulse at $170 \mathrm{ppm}$ (bottom left), soft pulse at 250 ppm (bottom right). The first contour was set at $5 \times$ the noise rmsd. (C) $1 \mathrm{D}^{1} \mathrm{H}$ slices of ${ }^{1} \mathrm{H}$-detected TEDOR-based ${ }^{15} \mathrm{~N}$ selective filtered CH HETCOR spectra in $\mathrm{U}-{ }^{13} \mathrm{C},{ }^{15} \mathrm{~N}-\mathrm{CA}$ CTD-SP1, extracted at ${ }^{13} \mathrm{C}$ shifts shown as gray dashed lines in panel (B). Left to right: TEDOR filter and soft pulse turned off, soft pulse turned off, soft pulse at $170 \mathrm{ppm}$, soft pulse at $250 \mathrm{ppm}$. The MAS frequency was $60 \mathrm{kHz}$. Signals of $\tau$ tautomer and $\pi$ tautomer are shown in magenta and teal, respectively.

remain; and iii) ${ }^{15} \mathrm{~N}$ selective TEDOR filter with a soft pulse at $250 \mathrm{ppm}$, retaining all signals of the charged state, $\mathrm{C}^{\varepsilon 1}$ and $\mathrm{C}^{\gamma}$ of the $\pi$ tautomer as well as $\mathrm{C}^{\varepsilon 1}$ and $\mathrm{C}^{\delta 2}$ atoms of the $\tau$ tautomer. $\mathrm{C}^{\varepsilon 1}$ of anionic tautomers is always present in TEDOR filtered spectra, but has reduced peak intensity when ${ }^{15} \mathrm{~N}$ selective pulse is applied as C-N dipolar interaction with the non-selectively irradiated nitrogen atom is recoupled. The sequence was first tested on a crystalline L-histidine sample prepared at $\mathrm{pH}$ 6.0. The ${ }^{13} \mathrm{C}$ and ${ }^{15} \mathrm{~N} 1 \mathrm{D}$ CPMAS and 2D NCA spectra are shown in Figures 1D, E, respectively. The spectra clearly indicate the presence of two forms of L-histidine, the charged monohydrate and the $\tau$ tautomer, in approximately 2:1 ratio. As shown in Figure 1F, conventional ${ }^{13} \mathrm{C}$-detected TEDOR-based experiments are well suited for the determination of protonation states in this sample. To test the ${ }^{1} \mathrm{H}$-detected sequences proposed herein, three complementary experiments were performed. As shown in Figure 1G, ${ }^{15} \mathrm{~N}$ selective TEDOR-filtered CH HETCOR without or with a soft pulse at $250 \mathrm{ppm}$ (left and right panels, respectively) yield the sidechain signals of both protonation states, while ${ }^{15} \mathrm{~N}$ selective TEDOR-filtered CH HETCOR with soft pulse at $170 \mathrm{ppm}$ retains only $\mathrm{C}^{\varepsilon 1}$ resonance of the $\tau$ tautomer (chemical shifts provided in Supplementary Table S1). Water suppression was incorporated into the second Z-filter, allowing to record spectra on hydrated samples.

HIV-1 $\mathrm{CA}_{\mathrm{CTD}}-\mathrm{SP} 1$ (Figure 2A) contains a single His residue, His-226. The outstanding high spectral resolution in the 
microcrystalline $\mathrm{FD}-{ }^{13} \mathrm{C},{ }^{15} \mathrm{~N}-\mathrm{CA}_{\mathrm{CTD}}$-SP1 sample allows for the determination of histidine protonation and tautomeric states even in the ${ }^{13} \mathrm{C}$-detected mode (Figure 2B). The $\mathrm{C}^{\varepsilon 1}$ and $\mathrm{C}^{\gamma}$ resonances are present in $1 \mathrm{D}$ experiments, while the $\mathrm{C}^{\delta 2}$ resonance is absent in the ${ }^{15} \mathrm{~N}$ selective TEDOR-filtered ${ }^{13} \mathrm{C}$ CPMAS experiment with the soft pulse at $170 \mathrm{ppm}$ since its magnetization does not build up during the TEDOR block due to the very weak dipolar coupling to $\mathrm{N}^{\delta 1}$ (chemical shifts provided in Supplementary Table S2). The $2 \mathrm{D}{ }^{13} \mathrm{C}-{ }^{13} \mathrm{C}$ CORD spectrum clearly shows a single set of resonances, indicating the presence of only one histidine species (Figure 2C), although the protonation and tautomeric state cannot be determined without additional experiments. The three complementary ${ }^{1} \mathrm{H}$-detected TEDORbased ${ }^{15} \mathrm{~N}$ selective $\mathrm{CH}$ HETCOR spectra (Figure 2D) also indicate the presence of a single species, which is unambiguously assigned as $\tau$ tautomer. These ${ }^{1} \mathrm{H}$-detected $2 \mathrm{D}$ spectra contain no resonances of aromatic residues other than His (shown in black in the CH HETCOR spectrum) and Trp (these are weak or absent in the spectra of the deuterated sample), as only carbons attached to nitrogens are selected, making assignment of histidine resonances straightforward.

In contrast to the $\mathrm{FD}-{ }^{13} \mathrm{C},{ }^{15} \mathrm{~N}-\mathrm{CA}_{\mathrm{CTD}}-\mathrm{SP} 1$, the His-226 protonation state in $\mathrm{U}_{-}{ }^{13} \mathrm{C},{ }^{15} \mathrm{~N}-\mathrm{CA}_{\mathrm{CTD}}-\mathrm{SP} 1$ assemblies cannot be easily determined using the $1 \mathrm{D}{ }^{13} \mathrm{C}$-detected version of TEDOR-based ${ }^{15} \mathrm{~N}$ selective filtered experiments due to low resolution and spectral overlap (Figure $\mathbf{3 A}$ ). In contrast, the 2D ${ }^{1} \mathrm{H}$-detected TEDOR-based ${ }^{15} \mathrm{~N}$ selective filtered spectra (Figure 3B) suggest the presence of a small fraction of $\pi$ tautomer along with the predominant $\tau$ tautomer in this sample (chemical shifts provided in Supplementary Table S2).

In addition to the His signals, the indole ring signals of the Trp184 residue are also present in the ${ }^{1} \mathrm{H}$-detected TEDOR-based experiments when the soft pulse is either turned off or centered at $250 \mathrm{ppm}$. This is expected due to the nitrogen atom $\mathrm{N}^{\varepsilon 1}$ in the indole ring, which allows for magnetization build up on adjacent carbon atoms $\left(\mathrm{C}^{\delta 1}\right.$ and $\left.\mathrm{C}^{\varepsilon 2}\right)$ during TEDOR transfer. Tryptophan sidechain resonances appear much stronger in non-deuterated protein assemblies compared to the $\mathrm{FD}-{ }^{13} \mathrm{C},{ }^{15} \mathrm{~N}-\mathrm{CA}_{\mathrm{CTD}}-\mathrm{SP} 1$ and can be distinguished from those corresponding to the histidine based on chemical shift.

\section{CONCLUSION}

We demonstrated that ${ }^{1} \mathrm{H}$-detected 2D Z-filtered TEDOR experiments incorporating ${ }^{15} \mathrm{~N}$ selective filters permit

\section{REFERENCES}

Adams, M. J., Blundell, T. L., Dodson, E. J., Dodson, G. G., Vijayan, M., Baker, E. N., et al. (1969). Structure of Rhombohedral 2 Zinc Insulin Crystals. Nature 224, 491-495. doi:10.1038/224491a0

Bachovchin, W. W., and Roberts, J. D. (1978). Nitrogen-15 Nuclear Magnetic Resonance Spectroscopy. The State of Histidine in the Catalytic Triad of AlphaLytic Protease. Implications for the Charge-Relay Mechanism of Peptide-Bond Cleavage by Serine Proteases. J. Am. Chem. Soc. 100, 8041-8047. doi:10.1021/ ja00494a001 unambiguous assignment of histidine protonation and tautomeric states in microcrystalline proteins and protein assemblies. This approach combines all the advantages of fast MAS and proton detection. Extending the experiments to MAS frequencies of $110 \mathrm{kHz}$ and above can further improve the quality of data sets and allow unambiguous assignment of His protonation and tautomeric states in larger proteins and protein assemblies.

\section{DATA AVAILABILITY STATEMENT}

The raw data supporting the conclusions of this article will be made available by the authors, without undue reservation.

\section{AUTHOR CONTRIBUTIONS}

TP and AMG conceived the project and guided the work. RZ performed NMR experiments and analyzed the experimental data. CMQ assisted with the NMR experiments and data analysis. SS assigned the $\mathrm{CA}_{\mathrm{CTD}^{-}} \mathrm{SP} 1$ chemical shifts. $\mathrm{KKZ}$, BKG-P, and OP prepared samples of microcrystalline $\mathrm{CA}_{\mathrm{CTD}^{-}}$ SP1 assemblies. RZ and TP took the lead in writing the manuscript. All authors discussed the results and contributed to the manuscript preparation.

\section{FUNDING}

This work was supported by the National Institutes of Health (NIH Grants P50AI1504817 and R01AI129678). We acknowledge the support of the National Science Foundation (NSF Grant CHE0959496) for the acquisition of the $850 \mathrm{MHz}$ NMR spectrometer and of the National Institutes of Health (NIH Grant P30GM110758) for the support of core instrumentation infrastructure at the University of Delaware; and of the National Institutes of Health (NIH Grant S10OD012213) for the acquisition of the $750 \mathrm{MHz}$ NMR spectrometer at the University of Pittsburgh.

\section{SUPPLEMENTARY MATERIAL}

The Supplementary Material for this article can be found online at: https://www.frontiersin.org/articles/10.3389/fmolb.2021.767040/ full\#supplementary-material

Bertani, P., Raya, J., and Bechinger, B. (2014). ${ }^{15} \mathrm{~N}$ Chemical Shift Referencing in Solid State NMR. Solid State. Nucl. Magn. Reson. 61-62, 15-18. doi:10.1016/ j.ssnmr.2014.03.003

Bloembergen, N. (1949). On the Interaction of Nuclear Spins in a Crystalline Lattice. Physica 15, 386-426. doi:10.1016/0031-8914(49)90114-7

Blomberg, F., Maurer, W., and Rueterjans, H. (1977). Nuclear Magnetic Resonance Investigation of Nitrogen-15-Labeled Histidine in Aqueous Solution. J. Am. Chem. Soc. 99, 8149-8159. doi:10.1021/ja00467a005

Blow, D. M., Birktoft, J. J., and Hartley, B. S. (1969). Role of a Buried Acid Group in the Mechanism of Action of Chymotrypsin. Nature 221, 337-340. doi: $10.1038 / 221337 \mathrm{a} 0$ 
Campbell, I. D., Lindskog, S., and White, A. I. (1974). A Study of the Histidine Residues of Human Carbonic Anhydrase B Using $270 \mathrm{MHz}$ Proton Magnetic Resonance. J. Mol. Biol. 90, 469-489. doi:10.1016/0022-2836(74)90229-0

Delaglio, F., Grzesiek, S., Vuister, G., Zhu, G., Pfeifer, J., and Bax, A. (1995). NMRPipe: a Multidimensional Spectral Processing System Based on UNIX Pipes. J. Biomol. NMR 6, 277-293. doi:10.1007/bf00197809

Edwards, B. F. P., and Sykes, B. D. (1980). Nuclear Magnetic Resonance Evidence for the Coexistence of Several Conformational States of Rabbit Cardiac and Skeletal Tropomyosins. Biochemistry 19, 2577-2583. doi:10.1021/ bi00553a007

French, T. C., and Hammes, G. G. (1965). Relaxation Spectra of Ribonuclease. II. Isomerization of Ribonuclease at Neutral pH Values. J. Am. Chem. Soc. 87, 4669-4673. doi:10.1021/ja00949a002

Goddard, T. D., and Kneller, D. G. (2004). SPARKY 3. Univ. California, San Fransisco.

Hansen, A. L., and Kay, L. E. (2014). Measurement of Histidine pKa Values and Tautomer Populations in Invisible Protein States. Proc. Natl. Acad. Sci. 111, E1705-E1712. doi:10.1073/pnas.1400577111

Hass, M. A. S., Hansen, D. F., Christensen, H. E. M., Led, J. J., and Kay, L. E. (2008). Characterization of Conformational Exchange of a Histidine Side Chain: Protonation, Rotamerization, and Tautomerization of His61 in Plastocyanin from Anabaena Variabilis. J. Am. Chem. Soc. 130, 8460-8470. doi:10.1021/ ja801330h

Hoffee, P., Lai, C. Y., Pugh, E. L., and Horecker, B. L. (1967). The Function of Histidine Residues in Rabbit Muscle Aldolase. Proc. Natl. Acad. Sci. 57, 107-113. doi:10.1073/pnas.57.1.107

Hou, G., Yan, S., Trébosc, J., Amoureux, J.-P., and Polenova, T. (2013). Broadband Homonuclear Correlation Spectroscopy Driven by Combined $\mathrm{R} 2{ }_{\mathrm{n}}{ }^{\mathrm{V}}$ Sequences Under Fast Magic Angle Spinning for NMR Structural Analysis of Organic and Biological Solids. J. Magn. Reson. 232, 18-30. doi:10.1016/j.jmr.2013.04.009

Hu, J., Fu, R., Nishimura, K., Zhang, L., Zhou, H.-X., Busath, D. D., et al. (2006). Histidines, Heart of the Hydrogen Ion Channel from Influenza A Virus: toward an Understanding of Conductance and Proton Selectivity. Proc. Natl. Acad. Sci. 103, 6865-6870. doi:10.1073/pnas.0601944103

Hu, F., Luo, W., and Hong, M. (2010). Mechanisms of Proton Conduction and Gating in Influenza M2 Proton Channels from Solid-State NMR. Science 330, 505-508. doi:10.1126/science.1191714

Kilmartin, J. V., Breen, J. J., Roberts, G. C. K., and Ho, C. (1973). Direct Measurement of the $\mathrm{pK}$ Values of an Alkaline Bohr Group in Human Hemoglobin. Proc. Natl. Acad. Sci. 70, 1246-1249. doi:10.1073/pnas.70.4.1246

Kossiakoff, A. A., and Spencer, S. A. (1980). Neutron Diffraction Identifies His 57 as the Catalytic Base in Trypsin. Nature 288, 414-416. doi:10.1038/ $288414 \mathrm{a} 0$

Kossiakoff, A. A., and Spencer, S. A. (1981). Direct Determination of the Protonation States of Aspartic Acid-102 and Histidine-57 in the Tetrahedral Intermediate of the Serine Proteases: Neutron Structure of Trypsin. Biochemistry 20, 6462-6474. doi:10.1021/bi00525a027

Kovalevsky, A. Y., Chatake, T., Shibayama, N., Park, S.-Y., Ishikawa, T., Mustyakimov, M., et al. (2010). Direct Determination of Protonation States of Histidine Residues in a $2 \AA$ Neutron Structure of Deoxy-Human Normal Adult Hemoglobin and Implications for the Bohr Effect. J. Mol. Biol. 398, 276-291. doi:10.1016/j.jmb.2010.03.016

Kupce, E., Boyd, J., and Campbell, I. D. (1995). Short Selective Pulses for Biochemical Applications. J. Magn. Reson. Ser. B 106, 300-303. doi:10.1006/ jmrb.1995.1049

Kwon, B., Roos, M., Mandala, V. S., Shcherbakov, A. A., and Hong, M. (2019). Elucidating Relayed Proton Transfer through a His-Trp-His Triad of a Transmembrane Proton Channel by Solid-State NMR. J. Mol. Biol. 431, 2554-2566. doi:10.1016/j.jmb.2019.05.009

Lee, W., Tonelli, M., and Markley, J. L. (2015). NMRFAM-SPARKY: Enhanced Software for Biomolecular NMR Spectroscopy. Bioinformatics 31, 1325-1327. doi:10.1093/bioinformatics/btu830

Lewis, S. D., Johnson, F. A., and Shafer, J. A. (1976). Potentiometric Determination of Ionizations at the Active Site of Papain. Biochemistry 15, 5009-5017. doi:10.1021/bi00668a010

Lewis, S. D., Johnson, F. A., and Shafer, J. A. (1981). Effect of Cysteine-25 on the Ionization of Histidine-159 in Papain as Determined by Proton Nuclear
Magnetic Resonance Spectroscopy. Evidence for a Histidine-159-Cysteine-25 Ion Pair and its Possible Role in Catalysis. Biochemistry 20, 48-51. doi:10.1021/ bi00504a009

Li, S., and Hong, M. (2011). Protonation, Tautomerization, and Rotameric Structure of Histidine: a Comprehensive Study by Magic-Angle-Spinning Solid-State NMR. J. Am. Chem. Soc. 133, 1534-1544. doi:10.1021/ ja108943n

Liljas, A., Kannan, K. K., Bergstén, P.-C., Waara, I., Fridborg, K., Strandberg, B., et al. (1972). Crystal Structure of Human Carbonic Anhydrase C. Nat. New Biol. 235, 131-137. doi:10.1038/newbio235131a0

Loewenthal, R., Sancho, J., and Fersht, A. R. (1992). Histidine-aromatic Interactions in Barnase. J. Mol. Biol. 224, 759-770. doi:10.1016/00222836(92)90560-7

Maciejko, J., Kaur, J., Becker-Baldus, J., and Glaubitz, C. (2019). Photocycledependent Conformational Changes in the Proteorhodopsin Cross-Protomer Asp-His-Trp Triad Revealed by DNP-Enhanced MAS-NMR. Proc. Natl. Acad. Sci. USA 116, 8342-8349. doi:10.1073/pnas.1817665116

Maeda, M., Chatake, T., Tanaka, I., Ostermann, A., and Niimura, N. (2004). Crystallization of a Large Single crystal of Cubic Insulin for Neutron Protein Crystallography. J. Synchrotron Radiat. 11, 41-44. doi:10.1107/ s0909049503023859

Mance, D., Sinnige, T., Kaplan, M., Narasimhan, S., Daniëls, M., Houben, K., et al. (2015). An Efficient Labelling Approach to Harness Backbone and Side-Chain Protons in ${ }^{1} \mathrm{H}$-Detected Solid-State NMR Spectroscopy. Angew. Chem. Int. Ed. 54, 15799-15803. doi:10.1002/anie.201509170

Markley, J. L. (1975). Observation of Histidine Residues in Proteins by Nuclear Magnetic Resonance Spectroscopy. Acc. Chem. Res. 8, 70-80. doi:10.1021/ $\operatorname{ar} 50086 \mathrm{a} 004$

Miao, Y., Cross, T. A., and Fu, R. (2014). Differentiation of Histidine Tautomeric States Using ${ }^{15} \mathrm{~N}$ Selectively Filtered ${ }^{13} \mathrm{C}$ Solid-State NMR Spectroscopy. J. Magn. Reson. 245, 105-109. doi:10.1016/j.jmr.2014.06.005

Miao, Y., Fu, R., Zhou, H.-X., and Cross, T. A. (2015). Dynamic Short Hydrogen Bonds in Histidine Tetrad of Full-Length M2 Proton Channel Reveal Tetrameric Structural Heterogeneity and Functional Mechanism. Structure 23, 2300-2308. doi:10.1016/j.str.2015.09.011

Morcombe, C. R., and Zilm, K. W. (2003). Chemical Shift Referencing in MAS Solid State NMR. J. Magn. Reson. 162, 479-486. doi:10.1016/S1090-7807(03)00082-X

Movellan, K. T., Wegstroth, M., Overkamp, K., Leonov, A., Becker, S., and Andreas, L. B. (2020). Imidazole-Imidazole Hydrogen Bonding in the $\mathrm{pH}$-Sensing Histidine Side Chains of Influenza A M2. J. Am. Chem. Soc. 142, 2704-2708. doi:10.1021/jacs.9b10984

Munowitz, M., Bachovchin, W. W., Herzfeld, J., Dobson, C. M., and Griffin, R. G. (1982). Acid-base and Tautomeric Equilibriums in the Solid State: Nitrogen-15 NMR Spectroscopy of Histidine and Imidazole. J. Am. Chem. Soc. 104, 1192-1196. doi:10.1021/ja00369a007

Pelton, J. G., Torchia, D. A., Meadow, N. D., and Roseman, S. (1993). Tautomeric States of the Active-Site Histidines of Phosphorylated and Unphosphorylated IIIGlc, a Signal-Transducing Protein from Escherichia coli, Using TwoDimensional Heteronuclear NMR Techniques. Protein Sci. 2, 543-558. doi:10.1002/pro.5560020406

Perutz, M. F., and Mathews, F. S. (1966). An X-ray Study of Azide Methaemoglobin. J. Mol. Biol. 21, 199-202. doi:10.1016/0022-2836(66)90088-x

Perutz, M. F., Muirhead, H., Mazzarella, L., Crowther, R. A., Greer, J., and Kilmartin, J. V. (1969). Identification of Residues Responsible for the Alkaline Bohr Effect in Haemoglobin. Nature 222, 1240-1243. doi:10.1038/ $2221240 \mathrm{a} 0$

Perutz, M. F., Gronenborn, A. M., Clore, G. M., Fogg, J. H., and Shih, D. T.-b. (1985). The pKa Values of Two Histidine Residues in Human Haemoglobin, the Bohr Effect, and the Dipole Moments of a-helices. J. Mol. Biol. 183, 491-498. doi:10.1016/0022-2836(85)90016-6

Platzer, G., Okon, M., and Mcintosh, L. P. (2014). pH-Dependent Random Coil ${ }^{1} \mathrm{H}$, ${ }^{13} \mathrm{C}$, and ${ }^{15} \mathrm{~N}$ Chemical Shifts of the Ionizable Amino Acids: a Guide for Protein pK a Measurements. J. Biomol. NMR 60, 109-129. doi:10.1007/s10858-0149862-y

Plesniak, L. A., Connelly, G. P., Mcintosh, L. P., and Wakarchuk, W. W. (1996). Characterization of a Buried Neutral Histidine Residue in Bacillus Circulansxylanase: NMR Assignments, $\mathrm{pH}$ Titration, and Hydrogen Exchange. Protein Sci. 5, 2319-2328. doi:10.1002/pro.5560051118 
Shenderovich, I. G., Lesnichin, S. B., Tu, C., Silverman, D. N., Tolstoy, P. M., Denisov, G. S., et al. (2015). NMR Studies of Active-Site Properties of Human Carbonic Anhydrase II by Using ${ }^{15} \mathrm{~N}$-Labeled 4-Methylimidazole as a Local Probe and Histidine Hydrogen-Bond Correlations. Chem. Eur. J. 21, 2915-2929. doi:10.1002/chem.201404083

Shimba, N., Takahashi, H., Sakakura, M., Fujii, I., and Shimada, I. (1998). Determination of Protonation and Deprotonation Forms and Tautomeric States of Histidine Residues in Large Proteins Using Nitrogen-Carbon J Couplings in Imidazole Ring. J. Am. Chem. Soc. 120, 10988-10989. doi:10.1021/ja982153g

Stevens, T. J., Fogh, R. H., Boucher, W., Higman, V. A., Eisenmenger, F., Bardiaux, B., et al. (2011). A Software Framework for Analysing Solid-State MAS NMR Data. J. Biomol. NMR 51, 437-447. doi:10.1007/s10858-011-9569-2

Stryer, L., Kendrew, J. C., and Watson, H. C. (1964). The Mode of Attachment of the Azide Ion to Sperm Whale Metmyoglobin. J. Mol. Biol. 8, 96-IN10. doi:10.1016/s0022-2836(64)80152-2

Vasa, S. K., Singh, H., Grohe, K., and Linser, R. (2019). Assessment of a Large Enzyme-Drug Complex by Proton-Detected Solid-State NMR Spectroscopy without Deuteration. Angew. Chem. Int. Ed. 58, 5758-5762. doi:10.1002/ anie. 201811714

Vinod Chandran, C., Madhu, P. K., Kurur, N. D., and Bräuniger, T. (2008). Sweptfrequency Two-Pulse Phase Modulation (SWf-TPPM) Sequences with Linear Sweep Profile for Heteronuclear Decoupling in Solid-State NMR. Magn. Reson. Chem. 46, 943-947. doi:10.1002/mrc.2285

Wagner, J. M., Zadrozny, K. K., Chrustowicz, J., Purdy, M. D., Yeager, M., GanserPornillos, B. K., et al. (2016). Crystal Structure of an HIV Assembly and Maturation Switch. eLife 5, e17063. doi:10.7554/eLife.17063

Wei, Y., De Dios, A. C., and McDermott, A. E. (1999). Solid-State ${ }^{15} \mathrm{~N}$ NMR Chemical Shift Anisotropy of Histidines: Experimental and Theoretical Studies of Hydrogen Bonding. J. Am. Chem. Soc. 121, 10389-10394. doi:10.1021/ ja9919074

Zhou, D. H., and Rienstra, C. M. (2008). High-performance Solvent Suppression for Proton Detected Solid-State NMR. J. Magn. Reson. 192, 167-172. doi:10.1016/j.jmr.2008.01.012

Zhou, M. M., Davis, J. P., and Van Etten, R. L. (1993). Identification and pKa Determination of the Histidine Residues of Human Low-Molecular-Weight Phosphotyrosyl Protein Phosphatases: A Convenient Approach Using MLEV17 Spectral Editing Scheme. Biochemistry 32, 8479-8486. doi:10.1021/ bi00084a012

Conflict of Interest: The authors declare that the research was conducted in the absence of any commercial or financial relationships that could be construed as a potential conflict of interest.

Publisher's Note: All claims expressed in this article are solely those of the authors and do not necessarily represent those of their affiliated organizations, or those of the publisher, the editors and the reviewers. Any product that may be evaluated in this article, or claim that may be made by its manufacturer, is not guaranteed or endorsed by the publisher.

Copyright (C) 2021 Zadorozhnyi, Sarkar, Quinn, Zadrozny, Ganser-Pornillos, Pornillos, Gronenborn and Polenova. This is an open-access article distributed under the terms of the Creative Commons Attribution License (CC BY). The use, distribution or reproduction in other forums is permitted, provided the original author(s) and the copyright owner(s) are credited and that the original publication in this journal is cited, in accordance with accepted academic practice. No use, distribution or reproduction is permitted which does not comply with these terms. 